\title{
Effect of Single Clove Garlic Extract (Allium Sativum Linn) on Blood Sugar Levels, Malondialdehyde, Insulin Levels and Insulin Resistance (Experiments in Rats (Rattus Novergicus) Induced by Streptozotocin
}

\author{
Yeni Susanti*, Merryana Adriani, Annis Catur Adi \\ Universitas Airlangga Surabaya, Indonesia \\ *yenisusanti595@gmail.com
}

\begin{abstract}
Diabetes mellitus is a condition where there is an increase in plasma blood sugar levels from its normal value, namely $\geq 200 \mathrm{mg} / \mathrm{dl}$. Oral antidiabetic drugs mostly give unwanted side effects, so it is necessary to develop a traditional treatment system for diabetes mellitus which is relatively safe. The purpose of this study was to determine the effect of single clove garlic on decreasing blood sugar levels, decreasing malondialdehyde levels, increasing insulin levels, and decreasing insulin resistance in experimental rats induced by streptozotocin $50 \mathrm{mg} / \mathrm{KgBB}$. The design in this study used a Randomized Post Test Only Control Group Design. There are 6 groups, each group consists of 4 heads. (K0) Negative control group (normal diet), (K1) positive control group (normal diet + streptozotocin induction and no therapy), (K2) positive control group patent drug (normal diet + streptozotocin induction + metformin), (P1) Induction of streptozotocin and therapy of single clove garlic $50 \mathrm{mg} / \mathrm{kgBB},(\mathrm{P} 2)$ induction of streptozotocin and therapy of single clove of garlic $75 \mathrm{mg} / \mathrm{KgBB}$, (P3) of induction of streptozotocin and therapy of single clove of garlic $125 \mathrm{mg} / \mathrm{KgBB}$. The most effective dose in this study was $125 \mathrm{mg} / \mathrm{KgBB}$. Comparison test the mean of each group with the Manova test. The flavonoids in single clove garlic have been shown to be powerful agents to reduce the pathogenesis of diabetes and its complications. The anti-diabetic modulation effect of flavonoids reduces apoptosis and insulin resistance as well as increases insulin secretion and translocation of GLUT4.
\end{abstract}

Keywords : Blood Sugar, Insulin, Insulin Resistance, Malondialdehyde, Single Clove Garlic 


\section{STRADA Jurnal Ilmiah Kesehatan}

DOI: $10.30994 /$ sjik.v9i2.411

ISSN: 2252-3847 (print); 2614-350X (online)

Vol.9 No.2 November 2020 Page.954-963

\section{BACKGROUND}

Diabetes mellitus is one of the four priority non-communicable diseases in the world. From 1980 to 2015, diabetes sufferers quadrupled, namely 108 million to 415 million people suffering from diabetes. By 2040 it is estimated that the number of people with diabetes will be 642 million. In 2015, the prevalence of diabetes sufferers in Indonesia was ranked seventh in the world (International Diabetes Federation, 2015). Diabetes mellitus is a condition in which there is an increase in plasma blood sugar levels from its normal value, namely $\geq 200 \mathrm{mg} / \mathrm{dl}$ on a time blood sugar examination or $\geq 126 \mathrm{mg} / \mathrm{dl} \mathrm{during}$ fasting. Another term for diabetes mellitus is hyperglycemia. Hyperglycemia is caused by abnormal insulin secretion or insulin work disturbance (Johansen et al., 2005). The increasing prevalence of diabetes mellitus in Indonesia has led to an increase in the use of anti-diabetes drugs which have an effect on the prevalence of side effects. The potential side effects of nausea when using Metformin were $18.53 \%$ and Glimepiride $13.33 \%$. Glibenclamide has the potential to cause side effects of hypoglycemia $15.79 \%$ (Joddy Sutama Putra et al., 2017).

Hyperglycemia is a sign of diabetes mellitus, this disease still affects many people in Indonesia. Oral antidiabetic drugs mostly have unwanted side effects, so experts have developed a traditional treatment system for diabetes mellitus that is relatively safe (Djamaan et al., 2012). Garlic (allium sativum) has antioxidant activity, single clove local garlic has better antioxidant activity than other varieties. (Prasonto et al., 2017). The provision of antioxidants and polyphenol compound components shows that they can scavenge free radicals, reduce oxidative stress, and reduce TNF- $\alpha$ expression. Phytochemical compounds are able to manipulate with various mechanisms so that they can reduce diabetes complications through reduction of oxidative stress, ROS and TNF- $\alpha$ (A. K. Tiwari \& Rao, 2002). Garlic contains allicin which can be used as an alternative therapy for type 2 diabetes mellitus, allicin in its active form acts as an antibiotic and antidiabetic in the human body while ajoene acts as an anti-coagulant in the blood. (Lisiswanti \& Haryanto, 2017).

Single clove garlic is garlic that only has one clove. Single clove garlic has a compound content of 5-6 times higher than regular garlic. The phenolic compounds of single clove garlic are hydrogen proton donors and neutralize free radicals. Single clove garlic contains strong antioxidants, namely flavonoids (Brouwer, 2018). Flavonoids can lower blood sugar levels with their ability as antioxidants. Flavonoids are protective against $\beta$ cell damage as insulin-producing and can restore insulin receptor sensitivity in cells and even increase insulin sensitivity (Winarsi1 \&, Nurtjahjo Dwi Sasongko2, Agus Purwanto3, 2013).

Based on research (Tri Banuriawan, 2016) the single clove garlic content showed antioxidant activity of $212.169 \mathrm{ppm}$, total phenolic of $238.558 \mathrm{mg}$ GAE / gr and total flavonoids of $656.41 \mathrm{mg} \mathrm{QE} \mathrm{/} \mathrm{gr.} \mathrm{Flavonoids} \mathrm{are} \mathrm{able} \mathrm{to} \mathrm{increase,} \mathrm{stabilize,} \mathrm{and} \mathrm{maintain}$ insulin secretion, in humans and pancreatic beta cells (Mohan et al., 2014). Flavonoids represent a large class of at least 6000 phenolic compounds found in fruits, vegetables, nuts, seeds, chocolate, tea, soybeans, red wine, herbal and beverage products. Structurally, flavonoids consist of two aromatic rings ( $\mathrm{A}$ and $\mathrm{B}$ rings) connected by 3 -carbon chains that form an oxygenated heterocyclic ring ( $\mathrm{C}$ ring). There are six sub-classes of flavonoids including flavones, flavonols, flavanones, flavonols, isoflavones and anthocyanidins based on differences in the generic structure of ring $\mathrm{C}$, the functional group on the ring and the position where ring $\mathrm{B}$ is attached to ring $\mathrm{C}$. Within each subclass, individual compounds 


\section{STRADA Jurnal Ilmiah Kesehatan}

DOI: $10.30994 /$ sjik.v9i2.411

ISSN: 2252-3847 (print); 2614-350X (online)

Vol.9 No.2 November 2020 Page.954-963

are characterized by a pattern. hydroxylation and certain conjugations. Flavonoids which have the ability to scavenge free radicals and metal chelating (Arts \& Hollman, 2005).

Based on the background, this study aims to prove the effect of single clove garlic extract (allium sativum linn) on blood sugar levels, serum malondialdehyde, insulin levels and insulin resistance in streptozotocin-induced rats. Research result (Saputra et al., 2018) show the results that the streptozotocin (STZ) agent is very appropriate to be used to make experimental mice in experimental diabetes mellitus conditions.

\section{METHODS}

The research carried out was an experimental laboratory. The study used male Wistar rats (Rattus Norvegicus) induced by streptozotocin (STZ). The design in this study used a Randomized Post Test Only Control Group Design with a completely randomized design (CRD). Treatment of experimental animals, examination of blood sugar levels, serum malondialdehyde (MDA) levels, insulin levels and insulin resistance were carried out at the Laboratory of Biochemistry, Faculty of Medicine, Airlangga University, Surabaya. When the research was carried out in March 2020 - July 2020. The sample size used was determined using the Federer formula (1995). After calculating the required sample size amounted to 24 animals, then divided into 6 groups, each group consisting of 4 heads. K0) Negative control group (normal diet without STZ induction), (K1) DM positive control group (normal diet + STZ induction and no therapy), (K2) positive control group $\mathrm{DM}$ patent drug (normal diet $+\mathrm{STZ}$ induction + metformin), (P1) Induction of STZ and therapy of single clove garlic $50 \mathrm{mg} / \mathrm{KgBB}$, (P2) induction of STZ and therapy of single clove of garlic $75 \mathrm{mg} / \mathrm{KgBB}$, (P3) of induction of STZ and therapy of single clove of garlic $125 \mathrm{mg} / \mathrm{KgBB}$. Before treatment, mice were adapted for 7 days. After an adaptation period of 7 days, the rats were induced by STZ with a single dose of $50 \mathrm{mg} / \mathrm{KgBB}$ intraperitoneally which was dissolved into citrate buffer PH 4.5. The treatment group was given oral single clove garlic extract therapy for 14 days. Initial fasting blood sugar levels were measured 3 days after streptozotocin induction to obtain inclusion criteria, namely rats in a hyperglycemic condition. Measurement of fasting blood sugar levels (fasting 8-12 hours), malondialdehyde levels (MDA), insulin levels and insulin resistance were carried out after the treatment was complete. To determine the differences in the treatment of each group, the Tukey HSD analysis was carried out with a 95\% confidence level. If there is a significant difference $(\mathrm{p}<0.05)$, it is continued with the mean comparison test for each group with the Manova test then the data is processed using the SPSS program. This study has passed the examination of the Research Ethics Commission of the Faculty of Public Health, Airlangga University with Code of Ethics No: 39 / EA / KEPK / 2020

\section{RESULTS}

Table 1: Average and standard deviation of fasting blood sugar levels before treatment (n $=24$ )

\begin{tabular}{cccccc}
\hline No & Kelompok & n & Mean \pm SD & Min & Maks \\
\hline 1 & K0 & 4 & $105,00 \pm 13,140$ & 90 & 122 \\
\hline 2 & K1 & 4 & $402,75 \pm 76,160$ & 317 & 495 \\
\hline 3 & K2 & 4 & $393,00 \pm 80,32$ & 315 & 500 \\
\hline 4 & P1 & 4 & $370,75 \pm 83,611$ & 251 & 433 \\
\hline 5 & P2 & 4 & $390,75 \pm 115,025$ & 219 & 459 \\
\hline 6 & P3 & 4 & $344,45 \pm 81,47$ & 254 & 440 \\
\hline
\end{tabular}




\section{STRADA Jurnal Ilmiah Kesehatan}

DOI: $10.30994 /$ sjik.v9i2.411

ISSN: 2252-3847 (print); 2614-350X (online)

Vol.9 No.2 November 2020 Page.954-963

Table 1 shows that the highest average fasting blood sugar (GDP) before treatment was in the control group (K1) of $402.75 \pm 76.160 \mathrm{mg} / \mathrm{dL}$ and the lowest fasting blood sugar (GDP) was in the control group (K0) of $105,00 \pm 13,140 \mathrm{mg} / \mathrm{dL} \mathrm{mg}$. It appears that the injection of streptozotocin in experimental animals can increase blood sugar levels in the control group (K1, K2) and the treatment group (P1, P2, P3).

Table 2 Average and standard deviation of fasting blood sugar levels after treatment $(\mathrm{n}=$ 24)

\begin{tabular}{cccccc}
\hline No & Kelompok & n & Mean \pm SD & Min & Maks \\
\hline 1 & K0 & 4 & $101,75 \pm 10,242$ & 87 & 110 \\
\hline 2 & K1 & 4 & $329,00 \pm 24,124$ & 299 & 350 \\
\hline 3 & K2 & 4 & $89,25 \pm 12,500$ & 72 & 101 \\
\hline 4 & P1 & 4 & $111,75 \pm 22,261$ & 95 & 142 \\
\hline 5 & P2 & 4 & $88,50 \pm 10,082$ & 80 & 103 \\
\hline 6 & P3 & 4 & $78,75 \pm 3,500$ & 77 & 84 \\
\hline
\end{tabular}

Table 2 can be seen that the mean fasting blood sugar levels (GDP) of experimental animals after being treated with single suing garlic extract at various different doses, it can be seen that the mean fasting blood sugar levels have decreased, and the average fasting blood sugar levels are the lowest. There was a group (P3) who was given a single suing garlic extract at a dose of $125 \mathrm{mg} / \mathrm{KgBB}$. Based on the test using the general linear manova model analyzed with Wilk 'lambda, the significance value was $\mathrm{p}=0.000$ ( $\mathrm{p}$ $<0.05$ ), which means that there was a difference in the average fasting blood sugar levels of each group after being treated with suing garlic extract. single.

Table 3 mean and standard deviation of malondialdehyde levels in the control group and the treatment group $(\mathrm{n}=24)$

\begin{tabular}{cccccc}
\hline No & Kelompok & n & Mean \pm SD & Min & Maks \\
\hline 1 & K0 & 4 & $9,231 \pm 1,874$ & 6,45 & 10,47 \\
\hline 2 & K1 & 4 & $35,505 \pm 1,206$ & 34,55 & 36,84 \\
\hline 3 & K2 & 4 & $19,052 \pm 2,452$ & 15,63 & 20,87 \\
\hline 4 & P1 & 4 & $22,940 \pm 1,950$ & 20,65 & 25,37 \\
\hline 5 & P2 & 4 & $19,560 \pm 1,698$ & 17,13 & 20,80 \\
\hline 6 & P3 & 4 & $18,653 \pm 0,699$ & 17,99 & 19,64 \\
\hline
\end{tabular}

Table 3 shows the highest average MDA level in the group (K1), which is $35.505 \pm 1.206$ $\mathrm{nmol} / \mathrm{L}$ with a minimum value of 34.55 and a maximum of 36.84. Meanwhile, the lowest average MDA level in the group (P3) was $18.653 \pm 0.699 \mathrm{nmol} / \mathrm{L}$ with a minimum value of 17.99 and a maximum of 19.64. Based on the test using the general linear manova model analyzed with Wilk 'lambda, the significance value was $p=0.000(p<0.05)$, which means that there was a difference in the average levels of malondialdehyde in each group after being treated with single suing garlic extract.

Table 4. Mean and standard deviation of insulin levels in the control group and the treatment group $(\mathrm{n}=24)$

\begin{tabular}{cccccc}
\hline No & Kelompok & n & Mean \pm SD & Min & Maks \\
\hline 1 & K0 & 4 & $7,000 \pm 1,430$ & 5,2 & 8,6 \\
\hline 2 & K1 & 4 & $2,350 \pm 0,208$ & 2,1 & 2,6 \\
\hline 3 & K2 & 4 & $2,375 \pm 0,206$ & 2,1 & 2,6 \\
\hline 4 & P1 & 4 & $2,200 \pm 0,141$ & 2,1 & 2,4 \\
\hline 5 & P2 & 4 & $2,300 \pm 0,141$ & 2,2 & 2,5 \\
\hline
\end{tabular}




\section{STRADA Jurnal Ilmiah Kesehatan}

DOI: $10.30994 /$ sjik.v9i2.411

ISSN: 2252-3847 (print); 2614-350X (online)

Vol.9 No.2 November 2020 Page.954-963
6
P3
4
$2,400 \pm 0,081$
2,3
2,5

Table 4 shows that the mean insulin level shows the highest average insulin level in the group (K0), which is $7,000 \pm 1,430 \mathrm{mU} / \mathrm{mL}$ with a minimum value of 5.2 and a maximum of 8.6. While the lowest average insulin level in the group (P1) was 2,200 \pm $0.141 \mathrm{mU} / \mathrm{mL}$ with a minimum value of 2.1 and a maximum of 2.4. Based on the test using the general linear manova model analyzed with Wilk 'lambda, the significance value is $p=0.000(p<0.05)$, which means that there is a difference in the average insulin levels of each group after being treated with single suing garlic extract.

Table 5. Mean and standard deviation of insulin resistance in the control and treatment groups $(\mathrm{n}=24)$

\begin{tabular}{cccccc}
\hline No & Kelompok & n & Mean \pm SD & Min & Maks \\
\hline 1 & K0 & 4 & $5,7477 \pm 5,5430$ & 3,84 & 7,43 \\
\hline 2 & K1 & 4 & $0,5878 \pm 0,0491$ & 0,53 & 0,63 \\
\hline 3 & K2 & 4 & $0,5213 \pm 0,0701$ & 0,46 & 0,60 \\
\hline 4 & P1 & 4 & $0,4273 \pm 0,0243$ & 0,40 & 0,46 \\
\hline 5 & P2 & 4 & $0,5009 \pm 0,429$ & 0,46 & 0,56 \\
\hline 6 & P3 & 4 & $0,6622 \pm 0,1333$ & 0,54 & 0,84 \\
\hline
\end{tabular}

Table 5 shows that the average HOMA-IR value in the K1 group had insulin resistance more than> 1.85 with an average of $5.7477 \pm 5.5430$ with a minimum value of 3.84 and a maximum of 7.43, while the $\mathrm{K} 0$ group, $\mathrm{K} 2$, P1, P2, and P3 have values less than HOMAIR> 1.85 .

\section{DISCUSSION}

1. Effect of Single Siung Garlic on Decreasing Blood Sugar Levels

Measurement of early fasting blood sugar levels after streptozotocin (STZ) induction aims to ensure that the mice are in a hyperglycemic state. The results of the $50 \mathrm{mg} / \mathrm{kgBW}$ streptozotocin induction caused fasting blood glucose levels to increase in groups K1, K2, P1, P2, and P3. Increased fasting blood glucose levels increase because STZ damages pancreatic beta cells by way of DNA alkylation. STZ is able to induce varying degrees of disruption of normal glucose homeostasis in mice. Both the pharmacokinetic and pharmacodynamic actions of insulin are altered when different baseline blood glucose levels from STZ diabetic mice are selected for testing. These findings emphasize the importance of selecting a predetermined and aggregated glucose level when using STZ as a diabetogenic agent in experimental protocols evaluating new antidiabetic agents and insulin delivery systems. (Qinna \& Badwan, 2015). There is an increase in high blood glucose levels because pancreatic beta cells are unable to secrete insulin. STZ reactions to pancreatic $\beta$-cells are accompanied by characteristic changes in blood insulin and glucose concentrations leading to hyperglycemia and decreased levels of insulin in the blood (Szkudelski, 2001).

The difference in the average reduction in high blood sugar levels in the control group (K1) $329.00 \pm 24,124$ and the treatment group (P3) $78.75 \pm 3,500$ because single clove garlic has a strong antioxidant content, namely flavonoids (Brouwer, 2018). The mechanism of flavonoids in reducing blood glucose levels in rats is by stimulating the release of insulin in pancreatic beta cells to be secreted into the blood, besides flavonoids can also restore insullin receptor sensitivity in cells. (Atiqoh et al., 2011). Flavonoids have been shown to be powerful agents for reducing the pathogenesis of diabetes and its complications. The anti-diabetic modulation effect of flavonoids reduces apoptosis and 


\section{STRADA Jurnal Ilmiah Kesehatan}

DOI: $10.30994 /$ sjik.v9i2.411

ISSN: 2252-3847 (print); 2614-350X (online)

Vol.9 No.2 November 2020 Page.954-963

insulin resistance as well as increases insulin secretion and translocation of GLUT 4(AlIshaq et al., 2019). Flavonoids have attracted a lot of attention for their potential antidiabetic activity. Epidemiological studies show that a higher intake of flavonoids is associated with a reduced risk of developing type 2 diabetes mellitus.Experimental studies have shown that flavonoids can reduce postprandial blood glucose by inhibiting glucose digestion and transport in the small intestine, by increasing the removal of glucose in the tissues, and by protecting and regenerate damaged $\beta$ cells, and or increase pancreatic insulin secretion (Alkhalidy et al., 2018).

Another content in single clove garlic is saponins. Saponins as $\alpha$-glucosidase enzyme inhibitors that inhibit the breakdown of carbohydrates into glucose (Fiana \& Oktaria, 2016). The mechanism of action of saponins is the occurrence of pancreatic regeneration which causes an increase in the number of pancreatic $\beta$ cells and Langerhans islands so that insulin secretion will increase. Increased insulin secretion will help reduce blood glucose levels. The regeneration of pancreatic $\beta$ cells occurs due to the presence of quiescent cells in the pancreas which have the ability to regenerate (Firdous et al., 2009). Based on this study, there are 3 variations of the dosage, namely $50 \mathrm{mg} / \mathrm{KgBB}, 75 \mathrm{mg} /$ $\mathrm{KgBB}$, and $125 \mathrm{mg} / \mathrm{KgBB}$. Giving a single clove garlic extract can reduce blood sugar levels with the most effective dose of $125 \mathrm{mg} / \mathrm{KgBB}$.

\section{Effect of Single Clove Garlic on Decreasing Levels of Malondialdehyde (MDA)}

This study measured the content of Malondialdehyde (MDA) and the measurements were made after giving a single clove garlic extract. One of the decomposition products of lipid oxidation is MDA, which is also formed through the biosynthesis of prostaglandins, such as endoperoxidase from polyunsaturated fatty acids (PUFA). Increased levels of MDA are influenced by increased production of ROS. Thus, MDA is a marker to determine the presence of oxidative stress in cells. Malondialdehyde can be observed in plasma, serum, and various tissues such as kidney tissue which has been reported in diabetic patients (B. K. Tiwari et al., 2013). Oxidative stress occurs due to free radical activity that antioxidants cannot fight in the body, which is indicated by high levels of MDA in the blood. MDA is produced from free radicals that undergo lipid peroxidation which damages the membrane, then causes several damages such as DNA damage, cell death, and neurological disorders (Khajehnasiri et al., 2013). Free radicals are chemically reactive species that form in normal physiology but become dangerous if not extinguished by the antioxidant system. A critical balance exists between Reactive Oxygen Species (ROS) production and antioxidant defense mechanisms (Halliwell \& Whiteman, 2004).

The research that has been done shows the difference in the average reduction in MDA levels in the control group (K1) $35.505 \pm 1.206$ and (P3) $18.653 \pm 0.699$ due to the presence of bioactive compounds contained in single clove garlic extract such as flavonoids and polyphenols which act as antioxidants. Antioxidants are compounds that can delay, slow down, and prevent the process of lipid oxidation which plays a role in the MDA production process, thus reducing MDA levels. The ability of flavonoids as antioxidants is due to the fact that flavonoids act as free radical scavengers. Giving single clove garlic extract can inhibit the increase in MDA levels. The mechanism of inhibition of increasing MDA is the antioxidant content of flavonoids found in single clove garlic which works to capture Reactive Oxygen Species (ROS) against hydroxyl radicals, superoxide anions, peroxyl and alkoxyl radicals and as metal pegkellers. (Baba et al., 2007). In addition, the saponin content is also quite effective in relieving diabetes by reducing the 


\section{STRADA Jurnal Ilmiah Kesehatan}

DOI: $10.30994 /$ sjik.v9i2.411

ISSN: 2252-3847 (print); 2614-350X (online)

Vol.9 No.2 November 2020 Page.954-963

level of lipid peroxidation and increasing the antioxidant defense system in the serum, liver and pancreas (Elekofehinti et al., 2013).

\section{The Effect of Single Clove Garlic on Increasing Insulin Levels}

Published data (Pinent et al., 2008) demonstrated that there is a direct effect of flavonoids on insulin secretion, as well as prevention of beta cell apoptosis, and they may even act via proliferation modulation. The mechanism of action mainly involves its antioxidant properties, but other pathways may also occur. Insulin is a hormone consisting of a series of amino acids, produced by the beta cells of the pancreas gland. Under normal circumstances, when there is stimulation of these beta cells, insulin is synthesized and then secreted into the blood according to the body's needs for blood glucose regulation. Physiologically, good blood glucose regulation is regulated together with the glucagon hormone secreted by the alpha cells of the pancreas gland (Manaf, 2009).

In this study the average difference in the increase in insulin levels in the control group (K1) was 2,350 \pm 0.208 and the treatment group (P3) was 2,400 \pm 0.081 there was an increase in insulin levels, it is thought that the active compound of single clove garlic extract acts as an antioxidant that can prevent and reduce free radicals so that increase the sensitivity of insulin receptors and cause glucose to be taken up by cells to be metabolized.

According to (Lugasi et al., 2003) flavonoids are able to scavenge free radicals or function as natural antioxidants. This antioxidant activity allows flavonoids to capture or neutralize free radicals (such as ROS or RNS) associated with phenolic OH groups so as to improve the state of damaged tissue. The action of flavonoids in diabetes mellitus is to avoid glucose absorption or to improve glucose tolerance. Flavonoids stimulate glucose uptake in peripheral tissues, regulate the activity and expression of enzymes involved in carbohydrate metabolic pathways and can act as insulin (insulino-mimetic) by influencing the insulin signaling mechanism. Natural food products have been used to combat human disease for thousands of years. Natural flavonoids including flavones, flavonols, flavanones, flavonols, isoflavones and anthocyanidins have been proposed as effective supplements for the management and prevention of diabetes and its long-term complications based on in vitro and animal models. (Vinayagam \& Xu, 2015).

\section{Effect of Single Clove Garlic on Decreasing Insulin Resistance (HOMA-IR)}

Homeostasis model of assessment-IR (HOMA). The HOMA IR method is the most commonly used method because it is easy to do and can estimate insulin sensitivity from fasting glucose concentrations and fasting plasma insulin levels. The relationship between glucose levels and insulin levels during basal conditions illustrates the balance between insulin secretion and the effect of glucose utilization in target organs such as the liver. The HOMA IR model can be used to measure insulin resistance in humans as well as mice and rats (Esteghamati et al., 2010).

(Lee et al., 2006) stated that insulin resistance causes insulin-mediated glucose use in peripheral tissues to be reduced. Insulin deficiency conditions can cause failure of the phosphorylation of the Insulin Receptor Substrate (IRS) complex, decreased GLUT4 translocation and glucose oxidation that causes glucose to be unable to enter cells (only stay in the blood) (hyperglycemia) (Bloom William, 2002). The higher the IR Homa value (in the DM rat group), the uptake and use of glucose by the body's cells is disrupted, as a result the glucose levels in the blood increase.

In this study there was an increase in the average insulin resistance based on the HOMA-IR method in the control group (K1) $0.5878 \pm 0.0491$ and the treatment group (P3) 


\section{STRADA Jurnal Ilmiah Kesehatan}

DOI: $10.30994 /$ sjik.v9i2.411

ISSN: 2252-3847 (print); 2614-350X (online)

Vol.9 No.2 November 2020 Page.954-963

$0.6622 \pm 0.1333$ This indicates that single clove garlic can improve insulin resistance. The antioxidant content in single clove garlic can suppress beta cell apoptosis without changing the proliferation of pancreatic beta cells. Antioxidants can scavenge free radicals, thereby reducing insulin resistance. Flavonoids might reduce inflammatory cytokine production through down-regulation of NF- $\kappa \mathrm{B}$ expression in the inflammatory pathway and regulating the IRS-1-PI3-K-PKB / Akt insulin pathway and thereby increasing GLUT4 expression. Potential of flavonoid compounds as effective and safe drugs for the treatment of insulin resistance and diabetes. Consistently, in treatment studies with moderate and high doses of total flavonoids from reducing blood FPG and P2hPG and stimulating insulin secretion in resistant mice, total flavonoids as a therapeutic effect (Yang et al., 2017).

\section{CONCLUSION}

The intervention of single clove garlic at a dose of $50 \mathrm{mg} / \mathrm{KgBB}, 75 \mathrm{mg} / \mathrm{KgBB}$, and 125 $\mathrm{mg} / \mathrm{KgBB}$ has an effect on reducing blood sugar levels, decreasing levels of malondialdehyde (MDA), increasing insulin levels, and decreasing insulin resistance in experimental mice (Rattus Novergicus) induced by Streptozotocin $50 \mathrm{mg} / \mathrm{KgBB}$.

\section{REFERENCES}

Al-Ishaq, R. K., Abotaleb, M., Kubatka, P., Kajo, K., \& Büsselberg, D. (2019). Flavonoids and their anti-diabetic effects: Cellular mechanisms and effects to improve blood sugar levels. Biomolecules. https://doi.org/10.3390/biom9090430

Alkhalidy, H., Wang, Y., \& Liu, D. (2018). Dietary flavonoids in the prevention of T2D: An overview. In Nutrients. https://doi.org/10.3390/nu10040438

Arts, I. C. W., \& Hollman, P. C. H. (2005). Polyphenols and disease risk in epidemiologic studies. In The American journal of clinical nutrition. https://doi.org/10.1093/ajcn/81.1.317s

Atiqoh, H., Wardani, R. S., \& Wulandari, M. (2011). ANTIDIABETES TEST FOR ROSELLA FLOWER INFUSION (Hibiscus sabdariffa Linn.) IN GLUCOSE INDUCED WISTAR MALE WHITE RATS. Jurnal.Unimus.Ac.Id 4.

Baba, S., Osakabe, N., Kato, Y., Natsume, M., Yasuda, A., Kido, T., Fukuda, K., Muto, Y., \& Kondo, K. (2007). Continuous intake of polyphenolic compounds containing cocoa powder reduces LDL oxidative susceptibility and has beneficial effects on plasma HDL-cholesterol concentrations in humans. American Journal of Clinical Nutrition. https://doi.org/10.1093/ajen/85.3.709

Bloom William, D. W. F. (2002). Histology Textbook Edition 12.

Brouwer, J. V. (2018). Single Clove Garlic Extract on Lipoprotein Lipase Enzyme Activity in Hypercholesterol Rats. Wijaya Kusuma Medical Scientific Journal. https://doi.org/10.30742/jikw.v7i2.430

Djamaan, Q., Goenarwo, E., \& Mashoedi, I. (2012). Effect of ginger juice on blood glucose levels and histopathological features of pancreatic beta cells. Medical Science.

Elekofehinti, O. O., Kamdem, J. P., Kade, I. J., Rocha, J. B. T., \& Adanlawo, I. G. (2013). Hypoglycemic, antiperoxidative and antihyperlipidemic effects of saponins from Solanum anguivi Lam. fruits in alloxan-induced diabetic rats. South African Journal of Botany. https://doi.org/10.1016/j.sajb.2013.04.010

Esteghamati, A., Ashraf, H., Khalilzadeh, O., Zandieh, A., Nakhjavani, M., Rashidi, A., Haghazali, M., \& Asgari, F. (2010). Optimal cut-off of homeostasis model assessment of insulin resistance (HOMA-IR) for the diagnosis of metabolic syndrome: Third 


\section{STRADA Jurnal Ilmiah Kesehatan}

DOI: $10.30994 /$ sjik.v9i2.411

ISSN: 2252-3847 (print); 2614-350X (online)

Vol.9 No.2 November 2020 Page.954-963

national surveillance of risk factors of non-communicable diseases in Iran (SuRFNCD-2007). Nutrition and Metabolism. https://doi.org/10.1186/1743-7075-726

Fiana, N., \& Oktaria, D. (2016). Effect of Saponin Content in Mahkota Dewa Fruit Flesh (Phaleria macrocarpa) on Decreasing Blood Glucose Levels. Majority.

Firdous, M., Koneri, R., Sarvaraidu, C. H., \& Shubhapriya, K. H. (2009). NIDDM Antidiabetic Activity of Saponins of Momordica Cymbalaria In StreptozotocinNicotinamide NIDDM Mice. Journal of Clinical and Diagnosis Research.

Halliwell, B., \& Whiteman, M. (2004). Measuring reactive species and oxidative damage in vivo and in cell culture: How should you do it and what do the results mean? In British Journal of Pharmacology. https://doi.org/10.1038/sj.bjp.0705776

International Diabetes Federation. (2015). Diabetes atlas seventh. Https://Www.Idf.Org/eLibrary/Epidemiology-Research/Diabetes-Atlas/13-Diabetes-Atlas-Seventh-

Edition.Html. https://www.idf.org/e-library/epidemiology-research/diabetes-atlas/13diabetes-atlas-seventh-edition.html

Joddy Sutama Putra, R., Achmad, A., \& Rachma Pramestutie, H. (2017). Incidence of Potential Side Effects of Anti-Diabetes Drug Therapy in Diabetes Mellitus Patients Based on Naranjo's Algorithm.

Pharmaceutical Journal of Indonesia, 2(2), 45-50. https://doi.org/10.21776/ub.pji.2017.002.02.3

Johansen, J. S., Harris, A. K., Rychly, D. J., \& Ergul, A. (2005). Oxidative stress and the use of antioxidants in diabetes: Linking basic science to clinical pratice. In Cardiovascular Diabetology. https://doi.org/10.1186/1475-2840-4-5

Khajehnasiri, F., Mortazavi, S. B., Allameh, A., Akhondzadeh, S., \& Hashemi, H. (2013). Total antioxidant capacity and malondialdehyde in depressive rotational shift workers. Journal of Environmental and Public Health. https://doi.org/10.1155/2013/150693

Lee, J. M., Okumura, M. J., Davis, M. M., Herman, W. H., \& Gurney, J. G. (2006). Prevalence and determinants of insulin resistance among U.S. adolescents: A population-based study. Diabetes Care. https://doi.org/10.2337/dc06-0709

Lisiswanti, R., \& Haryanto, F. P. (2017). Allicin in Garlic (Allium sativum) as an Alternative Therapy for Type 2 Diabetes Mellitus. Jurnal Majority.

Lugasi, A., Hóvári, J., Sági, K. V., \& Bíró, L. (2003). The role of antioxidant phytonutrients in the prevention of diseases. Acta Biologica Szegediensis.

Manaf. (2009). Internal Medicine Textbook: Insulin: Secretion Mechanism and Metabolic Aspects, Volume II (4th ed.). Fakultas Kedokteran Universitas Indonesia.

Mohan, V., Shah, S., Joshi, S., Seshiah, V., Sahay, B., Banerjee, S., Wangnoo, S., Kumar, A., Kalra, S., Unnikrishnan, A., Sharma, S., Rao, P., Akhtar, S., Shetty, R., \& Das, A. (2014). Current status of management, control, complications and psychosocial aspects of patients with diabetes in India: Results from the DiabCare India 2011 Study. Indian Journal of Endocrinology and Metabolism. https://doi.org/10.4103/2230-8210.129715

Pinent, M., Castell, A., Baiges, I., Montagut, G., Arola, L., \& Ardévol, A. (2008). Bioactivity of flavonoids on insulin-secreting cells. In Comprehensive Reviews in Food Science and Food Safety. https://doi.org/10.1111/j.1541-4337.2008.00048.x

Prasonto, D., Riyanti, E., \& Gartika, M. (2017). ANTIOXIDANT ACTIVITY TEST OF ONION EXTRACT (Allium sativum). ODONTO: Dental Journal. https://doi.org/10.30659/odj.4.2.122-128 


\section{STRADA Jurnal Ilmiah Kesehatan}

DOI: $10.30994 /$ sjik.v9i2.411

Qinna, N. A., \& Badwan, A. A. (2015). Impact of streptozotocin on altering normal glucose homeostasis during insulin testing in diabetic rats compared to normoglycemic rats. Drug Design, Development and Therapy. https://doi.org/10.2147/DDDT.S79885

Saputra, N. T., Suartha, I. N., \& Dharmayudha, A. A. G. O. (2018). Streptozotocin Diabetogenic Agent for Making Diabetes Mellitus Male White Rats. Udayana Veterinary Bulletin.https://doi.org/10.24843/bulvet.2018.v10.i02.p02

Szkudelski, T. (2001). The mechanism of alloxan and streptozotocin action in B cells of the rat pancreas. In Physiological Research.

Tiwari, A. K., \& Rao, J. M. (2002). Diabetes mellitus and multiple therapeutic approaches of phytochemicals: Present status and future prospects. In Current Science.

Tiwari, B. K., Pandey, K. B., Abidi, A. B., \& Rizvi, S. I. (2013). Markers of Oxidative Stress during Diabetes Mellitus. Journal of Biomarkers. https://doi.org/10.1155/2013/378790

Tri Banuriawan. (2016). Studi komparasi antioksidan bawang putih dengan bawang putih tunggal dengan menggunakan metode ekstraksi dan sonikasi. http://repository.ub.ac.id/151243/1/TRY BANURIAWAN.pdf

Vinayagam, R., \& Xu, B. (2015). Antidiabetic properties of dietary flavonoids: A cellular mechanism review. In Nutrition and Metabolism. https://doi.org/10.1186/s12986-0150057-7

Winarsi1, H., \& , Nurtjahjo Dwi Sasongko2, Agus Purwanto3, I. N. (2013). Cardamom leaf extract reduced the atherogenic index and blood sugar levels of induced diabetic rats. AGRITECH.

Yang, L., Wang, Z., Jiang, L., Sun, W., Fan, Q., \& Liu, T. (2017). Total Flavonoids Extracted from Oxytropis falcata Bunge Improve Insulin Resistance through Regulation on the IKK $\beta$ /NF- B Inflammatory Pathway. Evidence-Based Complementary and Alternative Medicine. https://doi.org/10.1155/2017/2405124 